VALLE, Vivian Cristina Lima López. CABRAL, Rodrigo Maciel. A responsabilização dos agentes públicos com o advento da lei no 13.655/2018: da teoria da irresponsabilidade estatal ao erro grosseiro. Revista Eletrônica Direito e Política, Programa de Pós-Graduação Stricto Sensu em Ciência Jurídica da UNIVALI, Itajaí, v.15, n.3, 30 quadrimestre de 2020. Disponível em: www.univali.br/direitoepolitica - ISSN 1980-7791

\title{
A RESPONSABILIZAÇÃO DOS AGENTES PÚBLICOS COM O ADVENTO DA LEI No 13.655/2018: DA TEORIA DA IRRESPONSABILIDADE ESTATAL AO ERRO GROSSEIRO
}

\author{
PUBLIC AGENTS LIABILITY WITH THE ADVENT OF THE LAW N. \\ 13.655/2018: FROM THE THEORY OF STATE IRRESPONSIBILITY TO THE \\ GROSS ERROR
}

\author{
Vivian Cristina Lima López Valle ${ }^{1}$ \\ Rodrigo Maciel Cabral ${ }^{2}$
}

\begin{abstract}
RESUMO
O presente estudo objetiva analisar a evolução do instituto da responsabilidade extracontratual do Estado, desde a teoria de irresponsabilidade até o atual ordenamento jurídico brasileiro. O advento da Lei no 13.655/2018 trouxe novas discussões no âmbito jurídico, especialmente pela gênese do "erro grosseiro", ressaltando-se seus supostos impactos na Lei de Improbidade Administrativa, no direito de regresso da Administração Pública contra o agente causador do dano e, ainda, em relação à culpa in vigilando. Até a regulamentação da nova LINDB por intermédio do Decreto no 9.830/2019, havia compreensão de que "erro grosseiro" e "culpa grave" eram sinônimos, no entanto, o Decreto distanciou os conceitos e afastou as supostas alterações legislativas. Assim, recorrendo-se aos critérios de solução de antinomias de normas jurídicas, imperioso destacar que a inclusão do erro grosseiro no ordenamento jurídico revela nova hipótese de responsabilização do agente público por danos ao erário, sem configuração de improbidade administrativa ou implicar em nova regulamentação do art. $37, \S 60$ da Constituição.
\end{abstract}

PALAVRAS-ChAVE: Responsabilidade; Agentes Públicos; Erro Grosseiro; Culpa Grave; Lei no 13.655/2018.

\footnotetext{
${ }^{1}$ Professora Titular de Direito Administrativo da Pontifícia Universidade Católica do Paraná. Doutora e Mestre em Direito do Estado pela Universidade Federal do Paraná. Especialista em Contratação Pública pela Universidade de Coimbra. Especialista em Direito Administrativo pelo Instituto Brasileiro de Estudos Jurídico - IBEJ. Coordenadora Adjunta do Curso de Direito da Pontifícia Universidade Católica do Paraná. Coordenadora do Curso de Especialização em Licitações e Contratos da Pontifícia Universidade Católica do Paraná. Membro do Instituto Paranaense de Direito Administrativo e do Instituto de Direito Romeu Felipe Bacellar. Membro da Comissão de Gestão Pública da Ordem dos Advogados do Brasil - Seção Paraná. Advogada especializada em Direito Público, fundadora do escritório Valle \& Sampaio - Advocacia e Consultoria Jurídica. vivianvalle@vallesampaio.com.br.

2 Bacharel em Direito pela Pontifícia Universidade Católica do Paraná - PUCPR; Pesquisador membro do Núcleo de Pesquisa em Políticas Públicas e Desenvolvimento Humano - NUPED/PUCPR; Pós-graduando em Direito Administrativo pelo Instituto de Direito Romeu Felipe Bacellar; Pósgraduando em Licitações e Contratos Administrativos pela Pontifícia Universidade Católica do Paraná - PUCPR; Advogado e Consultor no escritório Valle \& Sampaio - Advocacia e Consultoria Jurídica. rmacielcabral@gmail.com.
} 
VALLE, Vivian Cristina Lima López. CABRAL, Rodrigo Maciel. A responsabilização dos agentes públicos com o advento da lei no 13.655/2018: da teoria da irresponsabilidade estatal ao erro grosseiro. Revista Eletrônica Direito e Política, Programa de Pós-Graduação Stricto Sensu em Ciência Jurídica da UNIVALI, Itajaí, v.15, n.3, 30 quadrimestre de 2020. Disponível em: www.univali.br/direitoepolitica - ISSN 1980-7791

\section{ABSTRACT}

This study aims to analyze the evolution of the State non-contractual liability institute, from the theory of irresponsibility to the current Brazilian legal system. The advent of Law No. $13.655 / 2018$ brought new legal discussions, especially because of the genesis of the "gross mistake", highlighting its supposed impacts on the Law of Administrative Misconduct, on the Public Administration's right of return against the damage causing agent, and also regarding guilt "in vigilando". Until the regulation of the new LINDB through Decree No. 9.830/2019, there was an understanding that "gross error" and "gross guilt" were synonymous, however, the Decree distanced the concepts and rejected the supposed legislative changes. Thus, using the criteria for solutions of antinomies of legal norms, it is important to emphasize that the inclusion of gross error in the legal system reveals a new hypothesis of liability of the public agent for purse damage, without configuration of administrative misconduct or imply in a new regulation of the Constitution's art. $37, \S 6^{\circ}$.

KEYWORDS: Liability. Public agents. Gross error. Gross guilt. Law n. $13.655 / 2018$.

\section{INTRODUÇÃO}

Objetiva-se a análise da responsabilidade civil extracontratual do Estado e dos agentes públicos diante das transformações trazidas pelo advento da nova Lei de Introdução às Normas do Direito Brasileiro (e seu Decreto regulamentar), com a previsão da responsabilização de agentes públicos por dolo e erro grosseiro.

A responsabilidade civil extracontratual do Estado sempre foi tema de discussão no âmbito do Direito Administrativo, eis que se trata de matéria com notória evolução ao longo do tempo, reconhecendo-se também a diferente tratativa do tema em cada país. Primeiramente, registre-se que o tema ora abordado envolve somente as relações não estabelecidas mediante contratos administrativos, termos de parceria ou outros instrumentos contratuais firmados pelo Estado. Assim, importante destacar a conceituação de responsabilidade extracontratual do Estado, trazendo contornos do que o instituto transmite na vigência da Constituição de 1988, a qual se revela intimamente ligada ao dever de reparação de danos causados ao particular em decorrência de atos da Administração. ${ }^{3}$

\footnotetext{
3 Observe-se: "Entende-se por responsabilidade patrimonial extracontratual do Estado a obrigação que lhe incumbe de reparar economicamente os danos lesivos à esfera juridicamente garantida de outrem e que lhe sejam imputáveis em decorrência de comportamentos unilaterais, lícitos ou
} 
VALLE, Vivian Cristina Lima López. CABRAL, Rodrigo Maciel. A responsabilização dos agentes públicos com o advento da lei no 13.655/2018: da teoria da irresponsabilidade estatal ao erro grosseiro. Revista Eletrônica Direito e Política, Programa de Pós-Graduação Stricto Sensu em Ciência Jurídica da UNIVALI, Itajaí, v.15, n.3, 30 quadrimestre de 2020. Disponível em: www.univali.br/direitoepolitica - ISSN 1980-7791

Trata-se, portanto, de proteção jurídica conferida aos cidadãos contra danos que a Administração Pública possa Ihes causar, impondo-se o dever de reparação ao ente estatal ofensor.

Em um contexto de soberania inquestionável e inafastável do Estado, remontando-se às origens do Direito Público, o princípio que regia a matéria era o da irresponsabilidade do Estado, afastando-se a responsabilização da Administração Pública por atos unilaterais, salvo quando houvesse expressa previsão legal para o evento danoso vivenciado pelo cidadão. ${ }^{4}$ No Brasil, por exemplo, a figura do Imperador era inviolável, havendo previsão expressa no texto da Constituição de 1824 da impossibilidade de responsabilização deste. ${ }^{5}$

Em breve introdução da evolução do tema, como importante marco teórico para o desenvolvimento do Direito Administrativo e do instituto em discussão, faz-se necessário ressaltar o caso decidido em 1873 pelo Tribunal de Conflitos da França, decisão denominada arrêt Blanco. A menina Agnès Blanco fora atropelada por um trem de uma fábrica de tabaco em Bordeux, culminando em uma ação indenizatória que trouxe as seguintes contribuições para o tema: declaração de inaplicabilidade da responsabilidade proveniente do Código Civil para os casos que envolvem a responsabilização estatal; reconhecimento da especificidade da matéria no âmbito administrativo e possibilidade de adaptação do regime jurídico de responsabilização, em se tratando de serviço público; atribuição de competência administrativa para apreciação de casos semelhantes. ${ }^{6}$

Assim, diante do surgimento da ideia de que o Estado está submetido ao Direito e o consequente crescimento do reconhecimento de direitos aos indivíduos perante o ente estatal, o modelo de afastamento da responsabilidade estatal se

ilícitos, comissivos ou omissivos, materiais ou jurídicos" In: MELLO, Celso Antônio Bandeira de. Curso de Direito Administrativo. Malheiros Editores: São Paulo, 2012. P. 1009.

${ }^{4}$ MELLO, Celso Antônio Bandeira de. Curso de Direito Administrativo. Malheiros Editores: São Paulo, 2012. P. 1017.

5 Conforme texto da Constituição de 1824: "Art. 99. A Pessoa do Imperador é inviolavel, e Sagrada: Elle não está sujeito a responsabilidade alguma.". No entanto, ressalte-se que o art. 179, XXIX da Constituição de 1824 previa a possibilidade de responsabilização dos empregados públicos pelos abusos e omissões praticados no exercício de suas funções.

6 HACHEM, Daniel Wunder. Responsabilidade Civil do Estado por omissão: uma proposta de releitura da teoria da faute du service. Revista Eletrônica de Direito do Estado. N. 38, abril/junho de 2014. P. 3/4. 
VALLE, Vivian Cristina Lima López. CABRAL, Rodrigo Maciel. A responsabilização dos agentes públicos com o advento da lei no 13.655/2018: da teoria da irresponsabilidade estatal ao erro grosseiro. Revista Eletrônica Direito e Política, Programa de Pós-Graduação Stricto Sensu em Ciência Jurídica da UNIVALI, Itajaí, v.15, n.3, 30 quadrimestre de 2020. Disponível em: www.univali.br/direitoepolitica - ISSN 1980-7791

mostrou ultrapassado não mais prevalecendo, ${ }^{7}$ surgindo novas teorias acerca da responsabilização estatal.

No século XIX, apresenta-se o desenvolvimento da responsabilidade subjetiva do Estado, por meio da qual havia a diferenciação dos atos de império (ius imperium) - os quais não eram passíveis de responsabilização - e atos de gestão. Nestes segundos, era possível haver a responsabilização do Estado, desde que comprovada a culpa. ${ }^{8}$

À título representativo, note-se que a Constituição de 1891 mudou o posicionamento adotado anteriormente, passando a prever em seu artigo 92 que "Os funcionários públicos são estritamente responsáveis pelos abusos e omissões em que incorrerem no exercício de seus cargos, assim como pela indulgência ou negligência em não responsabilizarem efetivamente os seus subalternos", apresentando-se a responsabilidade subjetiva do Estado no Brasil, novamente, demonstrando-se a imprescindibilidade da demonstração do elemento subjetivo (culpa) dos seus agentes.

Somente com o advento da Constituição de 1946 o Brasil passou a prever a responsabilidade objetiva do Estado - independentemente de culpa da Administração Pública - pelos danos que seus agentes, naquela qualidade, causassem a outrem - com a possibilidade de ação regressiva em detrimento do agente, diante da comprovação de culpa. ${ }^{9}$ Neste contexto, o surgimento da responsabilidade objetiva revela que a prestação de atividades e benefícios à sociedade cria para o Estado um ônus de arcar com os danos que pode vir a causar, ${ }^{10}$ pelo que passa a assumir os riscos da atividade estatal.

\footnotetext{
7 MEDAUAR, Odete. Direito Administrativo Moderno. São Paulo: Revista dos Tribunais, 2008. P. 365.

${ }^{8}$ BACELLAR FILHO, Romeu Felipe. Direito administrativo. 4. ed. rev. e atual. São Paulo: Saraiva, 2008. P. 220.

9 "Art. 194 - As pessoas jurídicas de direito público interno são civilmente responsáveis pelos danos que os seus funcionários, nessa qualidade, causem a terceiros. Parágrafo único - Caber-Ihes-á ação regressiva contra os funcionários causadores do dano, quando tiver havido culpa destes."

${ }^{10}$ FREITAS, Daniel Castanha de. A responsabilidade civil do Estado por atos lícitos como resposta à aplicação do princípio constitucional da supremacia do interesse público. Fórum Administrativo FA, Belo Horizonte, ano 13, n .144, fev. 2013. Disponível em: <http://www.bidforum.com.br/bid/PDI0006.aspx?pdiCntd=85290>. Acesso em: 27 de junho de 2019.
} 
VALLE, Vivian Cristina Lima López. CABRAL, Rodrigo Maciel. A responsabilização dos agentes públicos com o advento da lei no 13.655/2018: da teoria da irresponsabilidade estatal ao erro grosseiro. Revista Eletrônica Direito e Política, Programa de Pós-Graduação Stricto Sensu em Ciência Jurídica da UNIVALI, Itajaí, v.15, n.3, 30 quadrimestre de 2020. Disponível em: www.univali.br/direitoepolitica - ISSN 1980-7791

A Constituição da República de 1988 consagrou em seu art. 37, §60 a responsabilidade objetiva do Estado abarcando tanto pessoas jurídicas de direito público quanto as pessoas jurídicas de direito privado prestadoras de serviço público como responsáveis pelos danos que seus agentes causarem a terceiros no exercício de sua atividade, ressalvando-se o direito de regresso contra os agentes diante da comprovação de dolo ou culpa deste.

No âmbito de responsabilização pessoal dos agentes públicos, destaca-se a criação da Lei no 8.429/1992, que criou a possibilidade de aplicação de sanções aos agentes públicos por atos de improbidade administrativa que causem enriquecimento ilícito, dano ao erário ou ofensa aos princípios da Administração Pública.

No entanto, o advento da Lei no 13.655/2018 alterou a Lei de Introdução às Normas do Direito Brasileiro com o acréscimo de artigos - destacando-se desde logo o art. 28, que prevê a responsabilização de agentes públicos "pessoalmente por suas decisões ou opiniões técnicas em caso de dolo ou erro grosseiro" levantou novas discussões sobre o tema. Tendo em vista que a Constituição prevê somente a responsabilização do agente público mediante comprovação de dolo ou culpa no tocante ao direito de regresso, o surgimento do erro grosseiro certamente não passa desapercebido, especialmente no tocante ao tema da responsabilidade extracontratual do Estado e aplicação das disposições da Lei de Improbidade Administrativa.

\section{A RESPONSABILIDADE EXTRACONTRATUAL DO ESTADO NA CONSTITUIÇÃO DE 1988}

É necessário e incontroverso afirmar que os problemas sociais vividos pela população guardam relação com a medida da prestação dos serviços públicos em um país, fazendo-se imprescindível o desenvolvimento de reflexão acerca da gestão destes serviços à luz da realidade experimentada pela população. ${ }^{11}$

\footnotetext{
${ }^{11}$ VALLE, Vivian Cristina Lima López. Serviço Público, Desenvolvimento Econômico e a Nova Contratualização da Administração Pública: o Desafio na Satisfação dos Direitos Fundamentais. In: BACELLAR FILHO, Romeu Felipe; GABARDO, Emerson; HACHEM,. Daniel Wunder (coord). Globalização, Direitos Fundamentais e Direito Administrativo: novas perspectivas para 0 desenvolvimento econômico e socioambiental. Belo Horizonte: Fórum, 2011. p. 284.
} 
VALLE, Vivian Cristina Lima López. CABRAL, Rodrigo Maciel. A responsabilização dos agentes públicos com o advento da lei no 13.655/2018: da teoria da irresponsabilidade estatal ao erro grosseiro. Revista Eletrônica Direito e Política, Programa de Pós-Graduação Stricto Sensu em Ciência Jurídica da UNIVALI, Itajaí, v.15, n.3, 30 quadrimestre de 2020. Disponível em: www.univali.br/direitoepolitica - ISSN 1980-7791

Assim, gize-se que o Estado tem um dever de buscar a realização do interesse coletivo e, justamente nesta busca e no uso de suas atribuições e prerrogativas, pode ocasionalmente causar danos aos particulares, devendo ressarcir aquele que for lesado. ${ }^{12}$ Note-se que, por exemplo, os serviços públicos estão vinculados ao preenchimento de direitos fundamentais $e,{ }^{13}$ portanto, se o Estado causar dano ao particular justamente na tentativa de proteção dos direitos fundamentais, tem o dever de reparação. ${ }^{14}$

Assim, conforme já asseverado, a Constituição da República de 1988 definiu em seu art. 37, $\S 6^{\circ}$ a responsabilidade objetiva do Estado, garantindo o direito de regresso da Administração Pública em face do agente causador do dano, desde que comprovado o elemento subjetivo da conduta do agente (dolo ou culpa, segundo o texto constitucional).

A concepção de que o Estado assume o risco pelo exercício de suas atividades e atribuições desencadeou 0 surgimento da responsabilidade objetiva, ${ }^{15}$ possibilitando a responsabilização do Estado independente da comprovação de

12 BACELLAR FILHO, Romeu Felipe. Responsabilidade Civil Extracontratual das Pessoas Jurídicas de Direito Privado Prestadoras de Serviço Público. Revista de Direito Administrativo e Constitucional - A \& C. Curitiba: Juruá, 2002. P. 20

13 PAIVA, Leonardo Lindroth de; LEINDORF, Cecilia de Aguilar. O usuário do serviço Público como consumidor: visões do direito administrativo e do consumidor e sua atual aplicação. In: BETTES, Janaína Maria; DE PAIVA, Leonardo Lindroth; Lucimara Deretti (coord.). Temas de Desenvolvimento e Socioambientalismo. Curitiba: CRV,2016. P. 167

14 Pondere-se sobre o tema do dever Estatal na consolidação dos direitos fundamentais: "Um direito fundamental social (que exija prestações positivas do Estado) não demanda somente uma obrigação imediata de patrocínio Estatal, mas sim um complexo encadeamento de atos governamentais que visem a satisfação da necessidade social. São necessárias, portanto, políticas públicas de implementação. [...] Enquanto provedor máximo, o Estado deve agir de forma a conciliar os investimentos e gastos públicos, pautando-se na previsão constitucional e legal dos direitos sociais." In: DOTTA, Alexandre Godoy; CABRAL, Rodrigo Maciel. Mínimo Existencial na Hermenêutica da Jurisprudência Brasileira Referente às Políticas Públicas Relativas ao Direito à Educação. Revista de Estudos Constitucionais, Hermenêutica e Teoria do Direito. a. 10. v.2., mai./ago. 2018, p. 139/140.

15 Não se trata de fazer prevalecer um interesse particular em detrimento dos princípios da indisponibilidade e supremacia do interesse público. Sobre o tema, assevera-se: "Daí por que, nesse ponto, é incompleta a ideia segundo a qual nas desapropriações o pagamento da indenização preserva o interesse particular. Preserva, antes de tudo, o interesse público de ver o patrimônio particular resguardado de qualquer espécie de medida estatal que, direta ou indiretamente, imponha um sacrifício de direito de modo especial e anormal ao direito de propriedade. Isso significa dizer que os interesses curados pelo Estado sempre estarão em posição de supremacia em relação aos interesses particulares. Por essa razão, entre eles existe apenas um confronto aparente, pois sempre hão de prevalecer o interesse público de toda a coletividade e a satisfação do bem comum; ou, em uma só voz: o interesse público." In: ZOCKUN, Maurício. Responsabilidade Patrimonial do Estado: Matriz Constitucional, a Responsabilidade do Estado por Atos Legislativos, a Obrigatoriedade da Prévia Indenização e a Responsabilidade Pessoal do Parlamentar. São Paulo: Malheiros, 2010. P. 93/94. 
VALLE, Vivian Cristina Lima López. CABRAL, Rodrigo Maciel. A responsabilização dos agentes públicos com o advento da lei no 13.655/2018: da teoria da irresponsabilidade estatal ao erro grosseiro. Revista Eletrônica Direito e Política, Programa de Pós-Graduação Stricto Sensu em Ciência Jurídica da UNIVALI, Itajaí, v.15, n.3, 30 quadrimestre de 2020. Disponível em: www.univali.br/direitoepolitica - ISSN 1980-7791

dolo ou culpa do ente Estatal e, com ela, a divisão da doutrina no tocante à teoria do risco administrativo: parte da doutrina opta peça adoção de um modelo de risco administrativo, com a possibilidade de exclusão e incidência de atenuantes na responsabilização do ente; enquanto outros compreendem pelo risco integral, sem hipótese de afastamento. ${ }^{16}$

Portanto, faz-se necessário abordar os elementos caracterizadores que fundamentam a responsabilização do Estado. O primeiro deles é o dano, trazido pela doutrina tradicional como elemento essencial sem o qual não há responsabilização da Administração Pública, mesmo que a conduta dela seja antijurídica (possivelmente ocasionando um dano no futuro). ${ }^{17}$ Aqui, revela-se importante destacar que a Constituição assegura a indenização por danos materiais e morais em seu art. 50, inciso $X$, não se afastando tal dispositivo quando o dano é causado pelo Estado ou seus agentes (nessa qualidade). Por outro lado, levando a questão à prática da judicialização, gize-se que o Supremo Tribunal Federal compreendeu pela ausência de repercussão geral "quando a controvérsia refere-se à indenização por dano moral decorrente de responsabilidade civil extracontratual", no julgamento do tema de repercussão geral no $880 .^{18}$

Portanto, no tocante a este primeiro elemento, cabe ressaltar que "el Estado es responsable por su obrar de cualquier naturaleza, tanto ilícito como también lícito ya que la antijuridicidad no es a su respecto la única fuente de de responsabilidad." 19

\footnotetext{
${ }^{16}$ FREITAS, Daniel Castanha de. A responsabilidade civil do Estado por atos lícitos como resposta à aplicação do princípio constitucional da supremacia do interesse público. Fórum Administrativo FA, Belo Horizonte, ano 13, $\mathrm{n} .144$, fev. 2013. Disponível em: <http://www.bidforum.com.br/bid/PDI0006.aspx?pdiCntd=85290>. Acesso em: 27 de junho de 2019.

${ }^{17}$ FARIA, Luzardo. Fundamentos para a adoção de um modelo preventivo de responsabilização civil do Estado. A\&C - Revista de Direito Administrativo \& Constitucional, Belo Horizonte, ano 17, n. 69 , jul./set. 2017, p. 6 .
}

18 "DANO MORAL. RESPONSABILIDADE CIVIL EXTRACONTRATUAL. MATÉRIA FÁTICA E INFRACONSTITUCIONAL. AUSÊNCIA DE REPERCUSSÃO GERAL. Não há repercussão geral quando a controvérsia refere-se à indenização por dano moral decorrente de responsabilidade civil extracontratual." (STF. ARE 945271 RG, Relator(a): Min. EDSON FACHIN, julgado em 17/03/2016, PROCESSO ELETRÔNICO DJe-124 DIVULG 15-06-2016 PUBLIC 16-06-2016 ).

${ }^{19}$ DELPIAZZO, Carlos. La responsabilidad estatal ante la huida del Derecho administrativo. A \& C Revista de Direito Administrativo e Constitucional. Belo Horizonte, ano 9, n. 35, jan./mar. 2009, p. 17 
VALLE, Vivian Cristina Lima López. CABRAL, Rodrigo Maciel. A responsabilização dos agentes públicos com o advento da lei no 13.655/2018: da teoria da irresponsabilidade estatal ao erro grosseiro. Revista Eletrônica Direito e Política, Programa de Pós-Graduação Stricto Sensu em Ciência Jurídica da UNIVALI, Itajaí, v.15, n.3, 30 quadrimestre de 2020. Disponível em: www.univali.br/direitoepolitica - ISSN 1980-7791

O segundo elemento é o nexo causal, a existência de uma correlação lógica entre a conduta da Administração Pública e o dano causado ao particular. Neste momento, cabe ressaltar que a doutrina desenvolve três teorias acerca do nexo causal, explicitadas por Rodrigo Valgas: a primeira é a teoria da equivalência das condições, pela qual não há distinção de causa menos ou mais relevante que culminou no evento danoso, permitindo inserir de números expressivos de causas e agentes geradores do dano; a segunda é a teoria da causalidade adequada, em que não basta que o fato seja condição de um resultado para responsabilização do agente, sempre que as condições não forem equivalentes; a terceira, adotada no Brasil, é a teoria dos danos diretos e imediatos (também denominada teoria da interrupção do nexo causal), que considera que nem todo fator que resulta no evento danoso é causa do dano, surgindo o dever de indenizar quando "o dano for efeito necessário de uma causa". ${ }^{20}$

Por fim, o último elemento seria uma atuação Estatal. No entanto, faz-se necessário dizer que a doutrina também diverge neste ponto: por um lado, há quem defenda que a responsabilidade objetiva do Estado depende de uma atuação, em razão da utilização do verbo "causar" pelo art. 37, §60, o que exprime a ideia de um ato concreto do agente público, enquanto a omissão ensejaria a comprovação da culpa do Estado e, portanto, deve ser analisada como responsabilidade subjetiva; ${ }^{21}$ sob outro viés, há defesa de que omissões estatais também seriam abordadas com base na responsabilidade objetiva do Estado. $^{22}$

\footnotetext{
${ }^{20}$ SANTOS, Rodrigo Valgas dos. Nexo Causal e Excludentes da Responsabilidade Extracontratual do Estado. In: FREITAS, Juarez (org.). Responsabilidade Civil do Estado. São Paulo: Malheiros, 2006. P. 275-280.

${ }^{21}$ GASPARINI, Diógenes. Direito Administrativo. São Paulo: Saraiva, 2008. P. 1043/1044.

22 Observe-se o seguinte trecho sobre o tema controverso: "Reina certa nebulosidade na doutrina e jurisprudência pátrias quanto a responsabilidade por omissão. Há afirmações no sentido de tratarse de responsabilidade subjetiva. Mas acórdãos do STF usam a expressão francesa faute du service, associada a casos em que o poder público deixou de tomar providências, ocorrendo o dano [...] Além do mais, a palavra francesa faute significa também erro, ausência. Daí Jacqueline Morand-Deviller considerar melhor empregar as expressões funcionamento defeituoso do serviço ou erro cometido no exercício do serviço, e arrola como exemplos: ausência de vigilância e controle, falta de manutenção, erros, negligências, omissões, trasos, inércia, abstenções, informações inexatas (Cours de droit administratif, 10 ed. 2007, p. 770-771)" In: MEDAUAR, Odete. Direito Administrativo Moderno. São Paulo: Revista dos Tribunais, 2008. P. 368.
} 
VALLE, Vivian Cristina Lima López. CABRAL, Rodrigo Maciel. A responsabilização dos agentes públicos com o advento da lei no 13.655/2018: da teoria da irresponsabilidade estatal ao erro grosseiro. Revista Eletrônica Direito e Política, Programa de Pós-Graduação Stricto Sensu em Ciência Jurídica da UNIVALI, Itajaí, v.15, n.3, 30 quadrimestre de 2020. Disponível em: www.univali.br/direitoepolitica - ISSN 1980-7791

A jurisprudência do Supremo Tribunal Federal acata a segunda tese, reconhecendo a responsabilidade objetiva do Estado também por omissões. ${ }^{23}$ Seriam, portanto, estes os elementos caracterizadores da responsabilidade objetiva do Estado, sem os quais a Constituição não permite a responsabilização de pessoas jurídicas de direito público ou pessoas jurídicas de direito privado prestadoras de serviço público.

Por outro lado, com base na teoria do risco administrativo, faz-se importante o apontamento de que tais elementos não bastam, devendo-se considerar no caso concreto a presença de causas excludentes da responsabilidade, sendo elas a força maior, a culpa da vítima e a culpa de terceiros, levando-se em consideração outrossim a culpa concorrente da vítima como causa atenuante. ${ }^{24}$

\section{O DIREITO DE REGRESSO DA ADMINISTRAÇÃO PÚBLICA EM FACE DO AGENTE CAUSADOR DO DANO}

O texto constitucional ainda abarcou em seu art. 37, §60 a possibilidade de a Administração Pública buscar regressivamente a reparação do dano em detrimento do agente causador, desde que comprovado o elemento subjetivo da conduta, delimitado constitucionalmente em dolo ou culpa. ${ }^{25}$ No Direito francês, a possibilidade de a Administração buscar o regresso em face do agente causador do dano sobreveio com os casos Laruelle e Deville: este primeiro

\footnotetext{
23 "Agravo regimental no recurso extraordinário com agravo. Administrativo. Estabelecimento público de ensino. Acidente envolvendo alunos. Omissão do Poder Público. Responsabilidade objetiva. Elementos da responsabilidade civil estatal demonstrados na origem. Reexame de fatos e provas. Impossibilidade. Precedentes. 1. A jurisprudência da Corte firmou-se no sentido de que as pessoas jurídicas de direito público respondem objetivamente pelos danos que causarem a terceiros, com fundamento no art. 37, § 60, da Constituição Federal, tanto por atos comissivos quanto por omissivos, desde que demonstrado o nexo causal entre o dano e a omissão do Poder Público. 2. O Tribunal de origem concluiu, com base nos fatos e nas provas dos autos, que restaram devidamente demonstrados os pressupostos necessários à configuração da responsabilidade extracontratual do Estado. 3. Inadmissível, em recurso extraordinário, o reexame de fatos e provas dos autos. Incidência da Súmula no 279/STF. 4. Agravo regimental não provido." In: STF. ARE 754778 AgR, Relator(a): Min. Dias Toffoli. Primeira Turma, julgado em 26/11/2013, DJe 18.12.2013, Publicação em 19.12.2013.
}

${ }^{24}$ DI PIETRO. Maria Sylvia Zanella. Direito Administrativo. 25a Ed. São Paulo: Atlas, 2012. P. 707.

25 Ressalte-se a importância do elemento subjetivo da conduta do agente público. Nos casos de responsabilização do Estado pela má conservação de rodovias federais, por exemplo, o Tribunal Regional Federal da $4^{a}$ Região entende salvaguardado o direito de regresso, desde que comprovado o dolo ou culpa do agente causador do dano. Exemplos: Apelações Cíveis 500117710.2016.4.04.7111, 5000024-09.2016.4.04.7121 e 5003377-23.2012.4.04.7210. 
VALLE, Vivian Cristina Lima López. CABRAL, Rodrigo Maciel. A responsabilização dos agentes públicos com o advento da lei no 13.655/2018: da teoria da irresponsabilidade estatal ao erro grosseiro. Revista Eletrônica Direito e Política, Programa de Pós-Graduação Stricto Sensu em Ciência Jurídica da UNIVALI, Itajaí, v.15, n.3, 30 quadrimestre de 2020. Disponível em: www.univali.br/direitoepolitica - ISSN 1980-7791

versava sobre o dano experimentado pelo Estado em razão de agente que utilizou viatura oficial fora da finalidade do serviço; já o segundo tratou de acidente de caminhão causado por um motorista vinculado ao Ministério de Reconstrução e do Urbanismo. ${ }^{26}$

Para tanto, existem algumas possibilidades de ação para a Administração buscar a reparação. A primeira delas é realizar o desconto em folha de pagamento do agente público, desde que haja anuência expressa por parte do servidor, com previsão legal que estabeleça o percentual máximo de desconto e seja assegurado ao servidor 0 direito ao contraditório e ampla defesa. ${ }^{27} \mathrm{~A}$ jurisprudência demonstra-se favorável a tais requisitos, ressaltando a importância do exercício do contraditório. ${ }^{28}$

A segunda conduta possível ao Estado é a cobrança da dívida pela via administrativa, criando uma espécie de autocomposição e celebração de Termo de Ajustamento de Conduta com o agente público. Tais instrumentos alternativos de resolução de conflitos vêm sendo incentivados pela legislação mais recente, em busca de soluções mais céleres, adequadas e menos custosas ao Estado. ${ }^{29}$

\footnotetext{
${ }^{26}$ SEVERO, Sérgio. Tratado de Responsabilidade Pública. São Paulo: Saraiva, 2009. n. p.

27 CARVAlho FILho, José dos Santos. Manual de Direito Administrativo. São Paulo: Atlas, 2014. P. 588-589.

28 "AGRAVO REGIMENTAL EM MANDADO DE SEGURANÇA. REPOSIÇÃO AO ERÁRIO. DESCONTO EM FOLHA. MAJORAÇÃO DO PERCENTUAL. IMPRESCINDIBILIDADE DE CONTRADITÓRIO E AMPLA DEFESA. 1. A Lei no 8.443/1992 (Lei Orgânica do TCU) autoriza o desconto integral ou parcelado da dívida nos vencimentos, salários ou proventos (art. 28, I). Não obstante, fixado o percentual do desconto pelo TCU, a sua majoração exige a observância prévia do contraditório e da ampla defesa. 2. Agravo regimental a que se nega provimento." In: STF - Ms 30248 Agr / Df - Distrito Federal, Relator(a): Min. Roberto Barroso, $1^{a}$ turma. data de julgamento: 07/10/2016, data de publicação: 26/10/2016.

29 Faz-se imprescindível ressaltar que há uma alteração paradigmática na adoção do consensualismo aplicado às relações do Estado. Neste sentido, explica-se: "O consensualismo permite interpretar o contrato como declaração negocial, caracterizando-o pelo consenso e pela igualdade assimétrica entre as partes. A dinâmica contratual passa a ser pautada por declarações negociais que somente admitirão a condição de potestade pública (com a autotutela e o regime de prerrogativas) quando os requisitos acima indicados estiverem presentes, passado a condição de autoridade como exceção e não regra contratual. [...] Não se nega a necessidade de a Administração Pública conservar o poder administrativo e a condição de autoridade. Mas se defende que essa condição seja excepcional ao atendimento das finalidades de interesse público. A utilização do consenso não implica renúncia da condição de autoridade. Estruturalmente a Administração Pública se submete a uma condição contratual com declarações negociais e um programa contratual gerido pelo consenso. Circunstancialmente age com unilateralidade, especificamente para evitar prejuízos ao interesse público." In: VALLE, Vivian Lima López. Contratos administrativos e um novo regime jurídico de prerrogativas contratuais na Administração Pública contemporânea: da unilateralidade ao consenso e do consenso à unilateralidade na relação contratual administrativa. Belo Horizonte: Fórum, 2018. p. 247-248.
} 
VALLE, Vivian Cristina Lima López. CABRAL, Rodrigo Maciel. A responsabilização dos agentes públicos com o advento da lei no 13.655/2018: da teoria da irresponsabilidade estatal ao erro grosseiro. Revista Eletrônica Direito e Política, Programa de Pós-Graduação Stricto Sensu em Ciência Jurídica da UNIVALI, Itajaí, v.15, n.3, 30 quadrimestre de 2020. Disponível em: www.univali.br/direitoepolitica - ISSN 1980-7791

Desde a sua criação, a Lei no 9.784/99 (Lei do Processo Administrativo Federal) prevê em seu artigo 20, inciso VI, a necessidade de observância ao critério de "adequação entre meios e fins, vedada a imposição de obrigações, restrições e sanções em medida superior àquelas estritamente necessárias ao atendimento do interesse público". Mais recentemente, a Lei no 13.129/2015 trouxe novas disposições sobre arbitragem, incluindo na Lei no 9.307/96 (Lei da Arbitragem) a possibilidade de a Administração Pública utilizar-se do instituto em questão para solucionar conflitos que versam sobre direitos patrimoniais disponíveis. ${ }^{30}$

Por sua vez, a Lei n. 13.140/2015 dispõe sobre a autocomposição de conflitos em que for parte a Administração Pública, destacando-se a possibilidade de criação de câmaras de prevenção e resolução administrativa de conflitos, que fomentam a utilização do meio consensual para resolução de conflitos entre órgãos e entes da Administração, para dirimir controvérsias entre particulares e pessoas jurídicas de direito público e para celebração de termo de ajustamento de conduta. ${ }^{31}$

Estas primeiras leis trazem mecanismos de solução de conflitos com um agente externo (árbitro ou mediador). Este terceiro possui atuação direta e determinante para resolver a situação contenciosa. Por outro lado, há possibilidade de uma forma de negociação direta entre as partes, aproximando ainda mais a Administração Pública e a outra parte da situação de conflito.

Desde logo adentrando ao tema ora em análise, é neste contexto que se insere a alteração legislativa em debate: a Lei no 13.655/2018 alterou a Lei de Introdução às Normas do Direito Brasileiro (Decreto-Lei no 4657/1942), inovando também no aspecto de resolução de conflitos por vias alternativas,

\footnotetext{
30 "Art. $1^{\circ}$ As pessoas capazes de contratar poderão valer-se da arbitragem para dirimir litígios relativos a direitos patrimoniais disponíveis. $\S 1^{\circ} \mathrm{A}$ administração pública direta e indireta poderá utilizar-se da arbitragem para dirimir conflitos relativos a direitos patrimoniais disponíveis."

31 "Art. 32. A União, os Estados, o Distrito Federal e os Municípios poderão criar câmaras de prevenção e resolução administrativa de conflitos, no âmbito dos respectivos órgãos da Advocacia Pública, onde houver, com competência para: I - dirimir conflitos entre órgãos e entidades da administração pública; II - avaliar a admissibilidade dos pedidos de resolução de conflitos, por meio de composição, no caso de controvérsia entre particular e pessoa jurídica de direito público; III - promover, quando couber, a celebração de termo de ajustamento de conduta."
} 
VALLE, Vivian Cristina Lima López. CABRAL, Rodrigo Maciel. A responsabilização dos agentes públicos com o advento da lei no 13.655/2018: da teoria da irresponsabilidade estatal ao erro grosseiro. Revista Eletrônica Direito e Política, Programa de Pós-Graduação Stricto Sensu em Ciência Jurídica da UNIVALI, Itajaí, v.15, n.3, 30 quadrimestre de 2020. Disponível em: www.univali.br/direitoepolitica - ISSN 1980-7791

especialmente em seu artigo 26 , que estabelece a possibilidade de formalização de termo de compromisso. ${ }^{32}$

Destarte, há previsão expressa para que o Estado possa firmar compromisso com o agente público causador do dano ao particular, assim eliminando irregularidade e situação contenciosa na aplicação do direito público. Portanto, a via administrativa é ampla ao se tratar da solução alternativa de conflitos, demonstrando-se apta à garantia de ressarcimento ao erário pelos danos causados por agente público.

Não sendo possível ou restando infrutífera a via administrativa para regresso contra o agente, cabível a via judicial a fim de ressarcir o erário. Note-se, no entanto, que o Estado somente poderá propor a ação de regresso contra os autores do dano após ter efetivamente pago a indenização ao particular que foi lesado, sendo este o momento de consumação do prejuízo ao erário e, somente então poderá habilitar-se ao exercício do direito de regresso. ${ }^{33}$ Ressalve-se, seguindo a linha de raciocínio proposta pelas decisões do Supremo Tribunal Federal, $^{34}$ assim como do Superior Tribunal de Justiça, ${ }^{35}$ tais ações são imprescritíveis para a Administração Pública, com fundamento no art. $37, \S 5^{\circ}$ da Constituição da República.

Desde logo, observa-se que o Estado possui diversas soluções a fim de buscar seu direito regressivo em face do agente público que lesou o particular,

\footnotetext{
32 "Art. 26. Para eliminar irregularidade, incerteza jurídica ou situação contenciosa na aplicação do direito público, inclusive no caso de expedição de licença, a autoridade administrativa poderá, após oitiva do órgão jurídico e, quando for o caso, após realização de consulta pública, e presentes razões de relevante interesse geral, celebrar compromisso com os interessados, observada a legislação aplicável, o qual só produzirá efeitos a partir de sua publicação oficial $\S 1^{\circ} 0$ compromisso referido no caput deste artigo: I - buscará solução jurídica proporcional, equânime, eficiente e compatível com os interesses gerais; II - (VETADO); III - não poderá conferir desoneração permanente de dever ou condicionamento de direito reconhecidos por orientação geral; IV - deverá prever com clareza as obrigações das partes, o prazo para seu cumprimento e as sanções aplicáveis em caso de descumprimento."
}

33 CARVAlho FILHO, José dos Santos. Manual de Direito Administrativo. São Paulo: Atlas, 2014. P. 590.

${ }^{34}$ STF. STF reconhece a imprescritibilidade de ação de ressarcimento decorrente de ato doloso de improbidade. Disponível em: http://www.stf.jus.br/portal/cms/verNoticiaDetalhe.asp?idConteudo=386249 Acesso em: 10 de julho de 2019.

35 Algumas decisões do STJ que reforçam a imprescritibilidade das ações de ressarcimento ao erário: Recursos Especiais no 1666484/SP, 1657362/SP, 1368395/SP, assim como AgRg no AREsp 513.006/RS e AgRg no REsp 1.319.757/SP. 
VALLE, Vivian Cristina Lima López. CABRAL, Rodrigo Maciel. A responsabilização dos agentes públicos com o advento da lei no 13.655/2018: da teoria da irresponsabilidade estatal ao erro grosseiro. Revista Eletrônica Direito e Política, Programa de Pós-Graduação Stricto Sensu em Ciência Jurídica da UNIVALI, Itajaí, v.15, n.3, 30 quadrimestre de 2020. Disponível em: www.univali.br/direitoepolitica - ISSN 1980-7791

ressaltando-se imprescindivelmente que 0 texto constitucional delimita 0 regresso à comprovação de dolo ou culpa por parte do servidor.

\section{AS DISPOSIÇÕES DA NOVA LEI DE INTRODUÇÃO ÀS NORMAS DO DIREITO BRASILEIRO (LEI No 13.655/2018)}

Conforme já abordado, é certo dizer que o instituto da responsabilidade civil extracontratual do Estado se desenvolveu e sofreu transformações ao longo do tempo, passando de um cenário de total irresponsabilidade à responsabilidade objetiva, que independe do elemento subjetivo da conduta.

Igualmente, desde logo assinale-se que, consequentemente, as ações regressivas do Estado em face do agente que causou a lesão às vítimas igualmente passaram por transformações.

No mais recente cenário de mutação da legislação, destaque-se que a sanção da Lei no $13.655 / 2018$ trouxe novas discussões no Direito, especialmente nas matérias relativas ao Direito Administrativo.

Conforme parecer emitido pela Comissão de Constituição e Justiça e de Cidadania, a nova Lei "tem a finalidade de aprimorar a qualidade decisória dos órgãos administrativos, judiciais e de controle nos três níveis da federação brasileira" e, dentre outros motivos, afirma ainda que "a proposta pretende tornar expressos alguns princípios e regras de interpretação e decisão que, segundo a doutrina atual, devem ser observados pelas autoridades administrativas ao aplicar a lei". ${ }^{36}$

Neste sentido, importante fazer breve abordagem das disposições trazidas pela Lei no 13.655/2018: vedação de tomada de decisão com base em valores jurídicos abstratos (art. 20); necessidade de motivação das decisões (art. 20, p. un.); necessidade de previsão das consequências práticas da decisão (art. 21); obrigação de observar as dificuldades dos gestores públicos, em relação à interpretação de normas que versam sobre gestão pública (art. 22); previsão

${ }^{36}$ CÂMARA DOS DEPUTADOS. Diário da Câmara dos Deputados: ano LXXII, No 189, sexta-feira, 27 de outubro de $2017 . \quad$ Disponível http://imagem.camara.gov.br/Imagem/d/pdf/DCD0020171027001890000.PDF\#page=324. Acesso em: 27 de fevereiro de 2020. 
VALLE, Vivian Cristina Lima López. CABRAL, Rodrigo Maciel. A responsabilização dos agentes públicos com o advento da lei no 13.655/2018: da teoria da irresponsabilidade estatal ao erro grosseiro. Revista Eletrônica Direito e Política, Programa de Pós-Graduação Stricto Sensu em Ciência Jurídica da UNIVALI, Itajaí, v.15, n.3, 30 quadrimestre de 2020. Disponível em: www.univali.br/direitoepolitica - ISSN 1980-7791

acerca da possibilidade de agentes públicos celebrarem compromissos com interessados, evitando situações contenciosas (art. 26); previsão de que o agente público responde pessoalmente por suas decisões ou opiniões técnicas, em caso de dolo ou erro grosseiro (art. 28), dentre outras. ${ }^{37}$

Em primeiro plano, é necessário destacar que a referida Lei possui diversos conceitos jurídicos indeterminados. ${ }^{38}$

Somente no parágrafo único do art. 21, é possível extrair os seguintes conceitos indeterminados: "quando for o caso", "modo proporcional e equânime", "interesses gerais", "em função das peculiaridades do caso" ônus "anormais ou excessivos". Logo, apresenta-se clara contrariedade, tendo em vista que a norma que proíbe a tomada de decisão com base em conceitos jurídicos abstratos (art. 20), dê margem ao agente público para valer-se de conceitos jurídicos indeterminados (art. 21, p. un.) na tomada de decisão. Neste momento, não há de se confundir conceito jurídico indeterminado com discricionariedade administrativa, tendo em vista que o primeiro se resolve com a aplicação do Direito, a segunda não. ${ }^{39}$

Diante dessas perspectivas trazidas pela nova Lei, o Instituto Brasileiro de Direito Administrativo (IBDA) promoveu seminário no qual aprovou enunciados relativos

\footnotetext{
37 A Lei no 13.655/2018 adicionou ao Decreto Lei no 4.657/1942 dez novos dispositivos e mais seus incisos e parágrafos, ressalvados os vetos presidenciais quando da sanção.

38 Veja-se, a título exemplificativo, o artigo 21, caput e parágrafo único da Lei no 13.655/2018: "Art. 21. A decisão que, nas esferas administrativa, controladora ou judicial, decretar a invalidação de ato, contrato, ajuste, processo ou norma administrativa deverá indicar de modo expresso suas consequências jurídicas e administrativas. Parágrafo único. A decisão a que se refere o caput deste artigo deverá, quando for o caso, indicar as condições para que a regularização ocorra de modo proporcional e equânime e sem prejuízo aos interesses gerais, não se podendo impor aos sujeitos atingidos ônus ou perdas que, em função das peculiaridades do caso, sejam anormais ou excessivos."

39 "La férrea distincción entre discrecionalidad y conceptos jurídicos indeterminados se presentó em Alemania - mayoritariamente - com antelación a la década de 1950 y hasta mediados de la década de 1970, época em la que comenzó a cobrar vigência la teoria unitaria. Se alude las diferentes operaciones lógicas para dar contenido a los conceptos indeterminados, que no constituyen um ejercicio de la facultad discrecional. [...] Em suma, em estas tesis los conceptos jurídicos indeterminados se resuelven por la aplicación del derecho, mientras que la discricionalidad no podría resolverse de esa manera." In: CORVALÁN, Juan Gustavo. Derecho Administrativo em transición: reconfiguración de la relación entre la Administración, las normas y el Poder Judicial. Ciudad Autónoma de Buenos Aires: Astrea, 2016. P. 106-107.
} 
VALLE, Vivian Cristina Lima López. CABRAL, Rodrigo Maciel. A responsabilização dos agentes públicos com o advento da lei no 13.655/2018: da teoria da irresponsabilidade estatal ao erro grosseiro. Revista Eletrônica Direito e Política, Programa de Pós-Graduação Stricto Sensu em Ciência Jurídica da UNIVALI, Itajaí, v.15, n.3, 30 quadrimestre de 2020. Disponível em: www.univali.br/direitoepolitica - ISSN 1980-7791

à interpretação da LINDB e seus impactos no Direito Administrativo, os quais auxiliam na interpretação de tais conceitos abertos. ${ }^{40}$

Em tentativa de regulamentar as novas disposições dos artigos 20 a 30 da Lei de Introdução às Normas do Direito Brasileiro, o Presidente da República editou o Decreto no 9.830/2019, contendo 25 artigos.

No tocante ao objeto central do presente trabalho, imperioso destacar o artigo 28 da nova LINDB, que estabeleceu a responsabilidade pessoal do agente público por suas decisões ou opiniões técnicas, em caso de dolo ou erro grosseiro. 0 primeiro elemento subjetivo da conduta já era previsto no próprio texto constitucional, inovando o legislador ao incluir o termo "erro grosseiro" no ordenamento jurídico.

Conforme demonstrar-se-á adiante, o surgimento do erro grosseiro levantou questionamentos em relação ao seu conteúdo jurídico, pois não é possível afirmar, somente no conteúdo da LINDB, se o elemento novo se assemelha à figura da culpa grave, culpa simples ou se trata de conceito apartado daqueles já existentes. Ainda, conforme se extrai diretamente do texto do art. 28, a alteração legislativa trouxe impactos na responsabilização dos agentes públicos sob diferentes aspectos, ressaltando-se as condenações fundadas na Lei de Improbidade Administrativa (Lei no 8.429/1992) e as ações de regresso movidas pela Administração Pública, alicerçadas no texto constitucional.

\section{ATUAIS PERSPECTIVAS de RESPONSABilizaÇÃo de Agentes PÚBLICOS COM FUNDAMENTO NO ERRO GROSSEIRO}

O texto original do artigo 28 da Lei no $13.655 / 2018$ possuía três parágrafos que delineavam a responsabilização do agente público, os quais foram vetados. À época, os juristas que auxiliaram na redação do então Projeto de Lei criticaram os vetos presidenciais, afirmando que foram "embasados em fundamentos

\footnotetext{
40 O enunciado no 8, por exemplo, afirma que "A expressão "equânime", contida no parágrafo único do art. 21 da LINDB, não transmite conceito novo que não esteja previsto no ordenamento jurídico, remetendo às ideias de isonomia, razoabilidade, proporcionalidade, equidade e ponderação dos múltiplos interesses em jogo." In: IBDA. Seminário promovido pelo IBDA aprova enunciados sobre a LINDB. Disponível em: http://ibda.com.br/noticia/seminariopromovido-pelo-ibda-aprova-enunciados-sobre-a-lindb. Acesso em: 02 de julho de 2019.
} 
VALLE, Vivian Cristina Lima López. CABRAL, Rodrigo Maciel. A responsabilização dos agentes públicos com o advento da lei no 13.655/2018: da teoria da irresponsabilidade estatal ao erro grosseiro. Revista Eletrônica Direito e Política, Programa de Pós-Graduação Stricto Sensu em Ciência Jurídica da UNIVALI, Itajaí, v.15, n.3, 30 quadrimestre de 2020. Disponível em: www.univali.br/direitoepolitica - ISSN 1980-7791

jurídicos insubsistentes" ressaltando que o erro grosseiro "terá lugar quando o agente público incorrer em negligência, imprudência ou imperícia irrecusáveis no exercício de seu mister". ${ }^{41}$

Seguindo a cronologia, o Tribunal de Contas da União apreciou a nova norma na tentativa de compreender o erro grosseiro. Primeiramente, por intermédio do Acórdão no 1.628/2018 (Plenário), de relatoria do Min. Benjamin Zymler, é possível observar que a noção de erro grosseiro inserida no ordenamento jurídico não modificou substancialmente o entendimento do TCU, que continuou utilizando a referência de "administrador médio" como base para qualificação da responsabilização de agentes públicos. ${ }^{42}$

Em acórdão posterior, enumerado 2.391/2018, de relatoria do mesmo Ministro, o Tribunal efetivamente abordou o tema, definindo erro grosseiro como "é o que poderia ser percebido por pessoa com diligência abaixo do normal, ou seja, que seria evitado por pessoa com nível de atenção aquém do ordinário, consideradas as circunstâncias do negócio. Dito de outra forma, o erro grosseiro é o que decorreu de uma grave inobservância de um dever de cuidado, isto é, que foi praticado com culpa grave". ${ }^{43}$ No Acórdão, há divisão dos diferentes tipos de erro, por gradação: erro leve, sendo aquele percebível por pessoa com diligência extraordinária (acima do normal), cujo efeito sobre a validade do negócio jurídico é não anulável; erro (sem qualificação) perceptível por pessoa com diligência

\footnotetext{
${ }^{41}$ MARQUES NETO, Floriano de Azevedo; FREITAS, Rafael Véras de. 0 artigo 28 da nova LINDB: um regime jurídico para o administrador honesto. Disponível em: https://www.conjur.com.br/2018-mai-25/opiniao-lindb-regime-juridico-administrador-honesto.

Acesso em: 02 de julho de 2019.

42 "41. Situação diversa é a do então Secretário de Gestão Administrativa, na condição de autoridade homologadora. 42. Primeiro, porque o plexo de atribuições do cargo exigiria que fossem adotados procedimentos para que as falhas não ocorressem. Era esperado desse gestor, por exemplo, que acionasse a procuradoria municipal para que se manifestasse sobre a matéria. 43. Segundo, porque esse autorizou, ao menos em parte, a contratação por dispensas de licitação de empresas cujos sócios eram funcionários da municipalidade e, com esse procedimento, induziu as pessoas a ele subordinadas, inclusive a mencionada pregoeira, a supor que a prática era lícita. 44 . Entendo, pois, que a conduta desse responsável foge do referencial do "administrador médio" utilizado pelo TCU para avaliar a razoabilidade dos atos submetidos a sua apreciação. Tratou-se, a meu ver, de erro grosseiro, que permite que os agentes respondam pessoalmente por seus atos, nos termos do art. 28 da Lei de Introdução às Normas do Direito Brasileiro (com redação dada pela Lei 13.655/2018)" In: TCU. Relatório de Auditoria no 024.434/2014-0, Acórdão no 1.628/2018 Plenário. Relator Min. Benjamin Zymler. Data da sessão: 18/07/2018.
}

43 TCU. Tomada de Contas Especial no 007.416/2013-0, Acórdão 2.391/2018 - Plenário. Relator Min. Benjamin Zymler. Data da sessão: 17/10/2018. 
VALLE, Vivian Cristina Lima López. CABRAL, Rodrigo Maciel. A responsabilização dos agentes públicos com o advento da lei no 13.655/2018: da teoria da irresponsabilidade estatal ao erro grosseiro. Revista Eletrônica Direito e Política, Programa de Pós-Graduação Stricto Sensu em Ciência Jurídica da UNIVALI, Itajaí, v.15, n.3, 30 quadrimestre de 2020. Disponível em: www.univali.br/direitoepolitica - ISSN 1980-7791

normal, sendo anulável; erro grosseiro, perceptível por pessoa com diligência abaixo do normal, cujo efeito sobre o negócio jurídico é anulável.

Por fim, o acórdão no 1941/2019 (Plenário), de relatoria de Augusto Nardes, o Tribunal reforçou a ideia de que o erro grosseiro é aquele que decorre de inobservância do dever de cuidado, praticado com culpa grave. Entretanto, este último acórdão deu conotação diferenciada para o tema, exemplificando um ato cometido com erro grosseiro, neste sentido: "decisão de gestor que desconsidera, sem a devida motivação, acórdão do TCU, pode ser tipificada como erro grosseiro para fins de responsabilização perante o Tribunal." ${ }^{44}$ Entretanto, em raciocínio decorrente, a existência de uma "devida motivação" pode justificar a tomada de uma decisão contrária ao entendimento do Tribunal, pelo que se conclui que o mero desatendimento a exigências do TCU não importa necessariamente em cometimento de erro grosseiro. ${ }^{45}$

Inicialmente, note-se que desde a lavratura do Acórdão 2.391/2018, o Tribunal de Contas da União vinculou o erro grosseiro a uma conduta praticada com culpa grave por parte do agente público, desde logo afastando a ideia de que os dois conceitos - erro grosseiro e culpa grave - se confundem. De todo modo, não há uma definição sobre o tema.

Diante deste cenário, repise-se que no Projeto de Lei do Senado no 349/2015 posteriormente aprovado e transformado na Lei no 13.655/2018 - não havia conceituação expressa de erro grosseiro. Os parágrafos do art. 28 que foram vetados afirmavam que não se considera caracterizado o erro grosseiro da decisão ou opinião baseadas em jurisprudência ou doutrina, em orientação geral ou em "interpretação razoável"; também previam uma espécie de apoio da entidade à qual o agente que responde por ato doloso ou de erro grosseiro estava vinculado, incluindo as despesas com a defesa do servidor. ${ }^{46}$

44 TCU. Representação no 023.072/2017-2, Acórdão 1.941/2019 - Plenário. Relator Min. Augusto Nardes. Data da sessão: 21/08/2019.

45 PALMA, Juliana Bonacorsi de. É erro grosseiro divergir do TCU? Divergência fundamentada não enseja responsabilidade do gestor. Disponível em: https://www.jota.info/opiniao-eanalise/colunas/controle-publico/e-erro-grosseiro-divergir-do-tcu-21112019. Acesso em: 10 de dezembro de 2019.

46 "§ 10 Não se considera erro grosseiro a decisão ou opinião baseada em jurisprudência ou doutrina, ainda que não pacificadas, em orientação geral ou, ainda, em interpretação razoável, 
VALLE, Vivian Cristina Lima López. CABRAL, Rodrigo Maciel. A responsabilização dos agentes públicos com o advento da lei no 13.655/2018: da teoria da irresponsabilidade estatal ao erro grosseiro. Revista Eletrônica Direito e Política, Programa de Pós-Graduação Stricto Sensu em Ciência Jurídica da UNIVALI, Itajaí, v.15, n.3, 30 quadrimestre de 2020. Disponível em: www.univali.br/direitoepolitica - ISSN 1980-7791

Somente em 10 de junho de 2019 sobreveio o conceito de "erro grosseiro" no ordenamento jurídico brasileiro, com o advento do Decreto no 9.830/2019, cujo objetivo é regulamentar as disposições da Lei no 13.655/2018. No tocante ao elemento ora analisado, faz-se imprescindível ressaltar o conteúdo do Decreto, que passou a prever em seu artigo 12 que "O agente público somente poderá ser responsabilizado por suas decisões ou opiniões técnicas se agir ou se omitir com dolo, direto ou eventual, ou cometer erro grosseiro, no desempenho de suas funções". Ainda, a definição do objeto vem, ainda em conceito aberto, no $§ 10$ deste artigo, afirmando que "Considera-se erro grosseiro aquele manifesto, evidente e inescusável praticado com culpa grave, caracterizado por ação ou omissão com elevado grau de negligência, imprudência ou imperícia". ${ }^{47}$

Assim, o novo Decreto confirmou o entendimento do Tribunal de Contas da União, vinculando o erro grosseiro a falhas do agente público cometidas com elevado grau de culpa (culpa grave), seja por uma ação em concreto, seja por omissão.

No tocante ao foco desta análise - responsabilidade do Estado e dos agentes públicos - destaque-se os principais impactos desta nova regulamentação: primeiramente, desenvolve-se tese de suposta alteração da Lei de Improbidade

mesmo que não venha a ser posteriormente aceita por órgãos de controle ou judiciais. $\S 200$ agente público que tiver de se defender, em qualquer esfera, por ato ou conduta praticada no exercício regular de suas competências e em observância ao interesse geral terá direito ao apoio da entidade, inclusive nas despesas com a defesa. § 30 Transitada em julgado decisão que reconheça a ocorrência de dolo ou erro grosseiro, o agente público ressarcirá ao erário as despesas assumidas pela entidade em razão do apoio de que trata o § $2^{\circ}$ deste artigo."

47 "Art. 12. O agente público somente poderá ser responsabilizado por suas decisões ou opiniões técnicas se agir ou se omitir com dolo, direto ou eventual, ou cometer erro grosseiro, no desempenho de suas funções.

$\S 1^{\circ}$ Considera-se erro grosseiro aquele manifesto, evidente e inescusável praticado com culpa grave, caracterizado por ação ou omissão com elevado grau de negligência, imprudência ou imperícia. §20 Não será configurado dolo ou erro grosseiro do agente público se não restar comprovada, nos autos do processo de responsabilização, situação ou circunstância fática capaz de caracterizar o dolo ou o erro grosseiro. $\$ 300$ mero nexo de causalidade entre a conduta e o resultado danoso não implica responsabilização, exceto se comprovado o dolo ou o erro grosseiro do agente público. $\S 4^{\circ} \mathrm{A}$ complexidade da matéria e das atribuições exercidas pelo agente público serão consideradas em eventual responsabilização do agente público. $\S 5^{\circ} 0$ montante do dano ao erário, ainda que expressivo, não poderá, por si só, ser elemento para caracterizar o erro grosseiro ou o dolo. §6० A responsabilização pela opinião técnica não se estende de forma automática ao decisor que a adotou como fundamento de decidir e somente se configurará se estiverem presentes elementos suficientes para o decisor aferir o dolo ou o erro grosseiro da opinião técnica ou se houver conluio entre os agentes. $\S 70$ No exercício do poder hierárquico, só responderá por culpa in vigilando aquele cuja omissão caracterizar erro grosseiro ou dolo. §8 $8^{\circ} 0$ disposto neste artigo não exime o agente público de atuar de forma diligente e eficiente no cumprimento dos seus deveres constitucionais e legais" 
VALLE, Vivian Cristina Lima López. CABRAL, Rodrigo Maciel. A responsabilização dos agentes públicos com o advento da lei no 13.655/2018: da teoria da irresponsabilidade estatal ao erro grosseiro. Revista Eletrônica Direito e Política, Programa de Pós-Graduação Stricto Sensu em Ciência Jurídica da UNIVALI, Itajaí, v.15, n.3, 30 quadrimestre de 2020. Disponível em: www.univali.br/direitoepolitica - ISSN 1980-7791

Administrativa (Lei no 8.429/1992); posteriormente, tem-se impacto na responsabilização dos agentes públicos também quando do exercício do direito de regresso da Administração Pública em detrimento do servidor que causou a lesão ao particular.

Em breve síntese, denote-se que a Lei de Improbidade dispõe sobre quatro modalidades diferentes de responsabilização dos agentes por ato de improbidade: a primeira categoria de atos que configuram improbidade administrativa respalda-se no art. 90 da Lei no 8.429/92, abrangendo a incidência da norma por atos que causam enriquecimento ilícito ao agente; a segunda envolve os atos de agentes públicos que causam prejuízo ao erário (art.100), sendo a única modalidade de ato de improbidade que possibilita a responsabilização do agente pelo elemento subjetivo tanto do dolo, quanto da culpa; a terceira categoria - inserida pela Lei Complementar no 157/2016 determina que constitui ato de improbidade "conceder, aplicar ou manter benefício financeiro ou tributário contrário ao que dispõem o caput e o $\S 10$ do art. 80-A da Lei Complementar no 116, de 31 de julho de 2003"; por fim, tratase do artigo 11 da Lei no 8.429/92, que estabelece como atos de improbidade aqueles que afrontam os princípios da administração pública, seja por ação ou omissão, violando deveres elencados no caput. ${ }^{48}$

Da análise do texto da própria Lei, observa-se que a única hipótese de condenação do agente público por conduta culposa é o art. 10, ou seja, aquelas condutas que causam dano ao erário. Note-se que a Lei de Improbidade não faz distinção entre culpa simples e culpa grave. A própria jurisprudência do Superior Tribunal de Justiça divide-se em relação ao elemento da culpa grave e simples, em algumas decisões posicionando-se a favor da ideia de que o ato ímprobo

\footnotetext{
48 "Art. $9^{\circ}$ Constitui ato de improbidade administrativa importando enriquecimento ilícito auferir qualquer tipo de vantagem patrimonial indevida em razão do exercício de cargo, mandato, função, emprego ou atividade nas entidades mencionadas no art. $1^{\circ}$ desta lei, e notadamente [...] Art. 10. Constitui ato de improbidade administrativa que causa lesão ao erário qualquer ação ou omissão, dolosa ou culposa, que enseje perda patrimonial, desvio, apropriação, malbaratamento ou dilapidação dos bens ou haveres das entidades referidas no art. $1^{\circ}$ desta lei, e notadamente [...] Art. 10-A. Constitui ato de improbidade administrativa qualquer ação ou omissão para conceder, aplicar ou manter benefício financeiro ou tributário contrário ao que dispõem o caput e o $\S 1^{\circ}$ do art. $8^{\circ}-\mathrm{A}$ da Lei Complementar $\mathrm{n}^{\circ} 116$, de 31 de julho de 2003. Art. 11. Constitui ato de improbidade administrativa que atenta contra os princípios da administração pública qualquer ação ou omissão que viole os deveres de honestidade, imparcialidade, legalidade, e lealdade às instituições, e notadamente $[\ldots]^{\prime \prime}$
} 
VALLE, Vivian Cristina Lima López. CABRAL, Rodrigo Maciel. A responsabilização dos agentes públicos com o advento da lei no 13.655/2018: da teoria da irresponsabilidade estatal ao erro grosseiro. Revista Eletrônica Direito e Política, Programa de Pós-Graduação Stricto Sensu em Ciência Jurídica da UNIVALI, Itajaí, v.15, n.3, 30 quadrimestre de 2020. Disponível em: www.univali.br/direitoepolitica - ISSN 1980-7791

exige a presença do dolo ou, ao menos, da culpa grave; ${ }^{49}$ em outros, exigindo-se a mera culpa simples. ${ }^{50}$ Por tais razões, o advento da nova LINDB e a criação do erro grosseiro reformulou o pensamento sobre o tema.

Partindo-se dos novos parâmetros para responsabilização pessoal do agente público e acatando a ideia de que os conceitos de "erro grosseiro" e "culpa grave" se igualam, passou-se a confirmar a impossibilidade de condenação dos agentes públicos por culpa simples, aduzindo-se que "a despeito de ainda permitir a configuração de ato de improbidade por culpa grave confere-se ao agente público a segurança necessária ao desenvolvimento do seu agir e à inovação na gestão pública [...] restringindo-se o âmbito de responsabilização administrativa". ${ }^{51}$

Igualmente, o posicionamento exaurido pelo Instituto Brasileiro de Direito Administrativo reúne os conceitos de erro grosseiro e culpa grave, indicando a necessidade de uma interpretação conjunta dos dispositivos da LIA e a LINDB, afastando a improbidade por culpa simples. ${ }^{52}$

\footnotetext{
49 "A improbidade é ilegalidade tipificada e qualificada pelo elemento subjetivo da conduta do agente. Por isso mesmo, a jurisprudência do STJ considera indispensável, para a caracterização de improbidade, que a conduta do agente seja dolosa, para a tipificação das condutas descritas nos artigos $9^{\circ}$ e 11 da Lei 8.429/92, ou pelo menos eivada de culpa grave, nas do artigo 10" In: STJ. AIA 30-AM, Corte Especial, Rel. Ministro Teori Albino Zavascki, DJe 28/9/2011.

50 STJ. AgRg no AREsp 654.406/SE, Rel. Ministro Herman Benjamin, 2a Turma, julgado em $17 / 11 / 2015$, DJe 04/02/2016.

51 VALIATI, Thiago Priess; MUNHOZ, Manoela Virmond. O impacto interpretativo da Lei $\mathrm{n}^{\circ}$ 13.655/2018 na aplicação da Lei de Improbidade Administrativa: a confiança no agente público de boa-fé para inovar na Administração Pública. Revista Brasileira de Direito Público - RBDP. Belo Horizonte, ano 16, n. 62, jul./set. 2018, P. 175

52 Este é o enunciado no 19: "A modalidade culposa de improbidade administrativa não se harmoniza com a Constituição, porque improbidade é ilegalidade qualificada pela intenção desonesta e desleal do agente. Não obstante, analisando-se a legislação infraconstitucional, o art.10 da Lei de Improbidade Administrativa deve ser interpretado de acordo com o art.28 da LINDB, afastando-se a possibilidade de configuração da improbidade sem a presença de erro grosseiro do agente (culpa grave) In: IBDA. Seminário promovido pelo IBDA aprova enunciados sobre a LINDB. Disponível em: http://ibda.com.br/noticia/seminario-promovidopelo-ibda-aprova-enunciados-sobre-a-lindb. Acesso em: 02 de julho de 2019.
} 
VALLE, Vivian Cristina Lima López. CABRAL, Rodrigo Maciel. A responsabilização dos agentes públicos com o advento da lei no 13.655/2018: da teoria da irresponsabilidade estatal ao erro grosseiro. Revista Eletrônica Direito e Política, Programa de Pós-Graduação Stricto Sensu em Ciência Jurídica da UNIVALI, Itajaí, v.15, n.3, 30 quadrimestre de 2020. Disponível em: www.univali.br/direitoepolitica - ISSN 1980-7791

Ainda, surge defesa no sentido de que a referida alteração legislativa revogou parcialmente a Lei de Improbidade Administrativa, à medida que estabeleceu uma restrição na responsabilização dos agentes públicos. ${ }^{53}$

Não se discordando da impossibilidade de aplicar sanções da Lei de Improbidade Administrativa por culpa simples e destacando-se que tais posicionamentos foram proferidos de forma anterior à edição do Decreto no 9.380/2019, é necessário repisar que os conceitos de "erro grosseiro" e de "culpa grave" não se confundem a partir do texto do Decreto. A previsão normativa estabelece que o erro grosseiro é uma consequência de uma atuação ou omissão do agente público, que a cometeu com culpa grave.

A Lei de Introdução às Normas do Direito Brasileiro (como o próprio nome define) é uma norma que possui efeito geral, ${ }^{54}$ não podendo ser colocada no mesmo patamar de normas especiais como é o caso da Lei de Improbidade Administrativa. Poder-se-ia imaginar que há incompatibilidade entre a LINDB e a LIA, no entanto, conforme as disposições da primeira, prevalece a máxima de que a criação de norma geral não revoga lei especial anterior. ${ }^{55}$ Outrossim, instaurando-se conflito entre os critérios cronológico e de especialidade da norma - quando uma norma mais antiga, especial, entra em conflito com norma geral nova - favorece-se a especialidade, pois a lei nova geral não afasta as disposições anteriores contidas na lei específica. ${ }^{56}$

Assim, seja pela existência de separação dos conceitos de erro grosseiro e culpa grave, seja pelo estabelecimento de prevalência dos critérios para solução de antinomia, discorda-se do posicionamento que acata suposta alteração da Lei de Improbidade Administrativa em decorrência do advento da Lei no 13.655/2018.

53 FERRAZ, Luciano. Alteração da LINDB revoga parcialmente Lei de Improbidade Administrativa. Disponível em: https://www.conjur.com.br/2018-mai-10/interesse-publicoalteracao-lindb-revoga-parcialmente-lei-improbidade. Acesso em: 05 de julho de 2019.

540 artigo $6^{\circ}$ da LINDB assim dispõe: "Art. $6^{\circ}$ A Lei em vigor terá efeito imediato e geral, respeitados o ato jurídico perfeito, o direito adquirido e a coisa julgada.".

55 "Art. $2^{\circ}$ Não se destinando à vigência temporária, a lei terá vigor até que outra a modifique ou revogue. $\S 1^{\circ} \mathrm{A}$ lei posterior revoga a anterior quando expressamente o declare, quando seja com ela incompatível ou quando regule inteiramente a matéria de que tratava a lei anterior. $\S 2^{\circ} \mathrm{A}$ lei nova, que estabeleça disposições gerais ou especiais a par das já existentes, não revoga nem modifica a lei anterior."

56 BOBBIO, Norberto. Teoria do Ordenamento Jurídico. Tradução de Maria Celeste Cordeiro Leite dos Santos. Brasília: Editora Universidade de Brasília, 1995. P. 108. 
VALLE, Vivian Cristina Lima López. CABRAL, Rodrigo Maciel. A responsabilização dos agentes públicos com o advento da lei no 13.655/2018: da teoria da irresponsabilidade estatal ao erro grosseiro. Revista Eletrônica Direito e Política, Programa de Pós-Graduação Stricto Sensu em Ciência Jurídica da UNIVALI, Itajaí, v.15, n.3, 30 quadrimestre de 2020. Disponível em: www.univali.br/direitoepolitica - ISSN 1980-7791

A partir de tais considerações, o mesmo raciocínio aplica-se ao direito de regresso da Administração em detrimento do agente público causador da lesão ao particular. Retome-se que a Constituição da República exige a presença do elemento subjetivo da conduta do servidor - delimitado em dolo ou culpa - para obter o direito de regresso. Sem a presença de tal elemento não há dever do agente em ressarcir a Administração em relação aos prejuízos que o Ente público suportou com a indenização dos particulares que sofreram o dano. ${ }^{57}$

Novamente partindo-se das considerações feitas pelo IBDA, desta vez no tocante ao Enunciado no 20, tem-se a ideia de que "O art.28 da LINDB, para os casos por ele especificados (decisões e opiniões técnicas) disciplinou o §6 $6^{\circ}$ do artigo 37 da Constituição, passando a exigir dolo ou erro grosseiro (culpa grave) também para fins da responsabilidade regressiva do agente público." ${ }^{\prime 58}$ No mesmo sentido, a relação de enunciados com base em precedentes interpretativos do Superior Tribunal de Justiça e das $4^{a}$ e $5^{a}$ câmaras cíveis do Tribunal de Justiça do Estado do Paraná traz, em seu enunciado de no 10 que "O artigo 10 da Lei 8.429/1992 foi alterado pela Lei 13.655/2018, não mais sendo admitida a caracterização de ato de improbidade administrativa que cause lesão ao erário na modalidade culposa. ${ }^{\prime 59}$ No entanto, estes dispositivos também pressupõem unidade dos conceitos de erro grosseiro e culpa grave. De fato, o advento da nova LINDB trouxe uma regulamentação do referido dispositivo constitucional, mas em aspecto diferente deste trazido pelo IBDA e pelo TJPR.

Perceba-se que a tratativa dada pela Constituição e pela Lei no 13.655/2018 é divergente no tocante à responsabilidade objetiva do Estado e responsabilidade dos agentes públicos: a Constituição prevê que a responsabilidade é objetiva, da

\footnotetext{
57 GUIMARÃES, Edgar. Contornos da Responsabilidade Patrimonial do Estado. In: HACHEM, Daniel Wunder; GABARDO, Emerson; SALGADO, Eneida Desiree (coord.). Direito Administrativo e Suas Transformações Atuais - homenagem ao professor Romeu Felipe Bacellar Filho: Anais do Seminário da Faculdade de Direito da Universidade Federal do Paraná. Curitiba: Íthala, 2016. P. 519.
}

${ }^{58}$ IBDA. Seminário promovido pelo IBDA aprova enunciados sobre a LINDB. Disponível em: http://ibda.com.br/noticia/seminario-promovido-pelo-ibda-aprova-enunciados-sobre-a-lindb. Acesso em: 02 de julho de 2019.

59 TJPR. Relação de enunciados com base em precedentes interpretativos do Superior Tribunal de Justiça e das $4^{a}$ e $5^{a}$ câmaras cíveis do Tribunal de Justiça do Estado do Paraná. 
VALLE, Vivian Cristina Lima López. CABRAL, Rodrigo Maciel. A responsabilização dos agentes públicos com o advento da lei no 13.655/2018: da teoria da irresponsabilidade estatal ao erro grosseiro. Revista Eletrônica Direito e Política, Programa de Pós-Graduação Stricto Sensu em Ciência Jurídica da UNIVALI, Itajaí, v.15, n.3, 30 quadrimestre de 2020. Disponível em: www.univali.br/direitoepolitica - ISSN 1980-7791

Administração Pública ou quem Ihe faça as vezes, pelos danos que seus agentes, nesta qualidade, causarem a outrem. Resguarda-se o direito de regresso em face do agente nos casos de dolo ou culpa; já a segunda Lei prevê responsabilidade pessoal do agente público por suas decisões e opiniões técnicas, nos casos em que agir com dolo ou erro grosseiro. Uma infere o ajuizamento de ação em face do Estado independentemente do elemento subjetivo da conduta do agente; outra diretamente em detrimento do agente, a depender de seu animus. Há, assim, um conflito entre uma norma hierarquicamente superior e mais antiga e uma norma hierarquicamente inferior, mas nova. Novamente recorrendo à pauta de conflitos entre critérios de resolução de antinomias de normas jurídicas, é necessário dizer que prevalece a hierarquia das normas, firmando-se que "o princípio lex posteriori derogat priori não vale quando a lex posterior é hierarquicamente inferior à lex prior". ${ }^{60}$ Portanto, o acionamento direto do agente público por ação ou omissão é incompatível com a Constituição.

Frise-se que o Supremo Tribunal Federal recentemente analisou a controvérsia em relação ao alcance do referido dispositivo constitucional, no que concerne à possibilidade de o particular que sofreu o dano ingressar com ação judicial contra o agente público responsável pelo ato que lhe prejudicou, conforme Tema de Repercussão Geral no 940 (leading case RE 1027633). ${ }^{61}$ O Tribunal fixou a tese de que "A teor do disposto no art. 37, § 60, da Constituição Federal, a ação por danos causados por agente público deve ser ajuizada contra o Estado ou a pessoa jurídica de direito privado prestadora de serviço público, sendo parte ilegítima para a ação o autor do ato, assegurado o direito de regresso contra o responsável nos casos de dolo ou culpa", vedando-se o ajuizamento direto em face do agente público. ${ }^{62}$

\footnotetext{
60 BOBBIO, Norberto. Teoria do Ordenamento Jurídico. Tradução de Maria Celeste Cordeiro Leite dos Santos. Brasília: Editora Universidade de Brasília, 1995. P. 107.

61 "RESPONSABILIDADE CIVIL - INDENIZAÇÃO - RÉU AGENTE PÚBLICO - ARTIGO 37, § 60, DA CONSTITUIÇÃO FEDERAL - ALCANCE - ADMISSÃO NA ORIGEM - RECURSO EXTRAORDINÁRIO REPERCUSSÃO GERAL CONFIGURADA. Possui repercussão geral a controvérsia alusiva ao alcance do artigo 37, § 60, da Carta Federal, no que admitida a possibilidade de particular, prejudicado pela atuação da Administração Pública, formalizar ação judicial contra o agente público responsável pelo ato lesivo." In: STF. RE 1027633 RG, Relator(a): Min. Marco Aurélio, julgado em 23/03/2017, Publicação em 21-11-2017.
}

${ }^{62}$ STF. Repercussão Geral no 940 - Responsabilidade civil subjetiva do agente público por danos causados a terceiros, no exercício de atividade pública. Disponível em: http://www.stf.jus.br/portal/jurisprudenciaRepercussao/verAndamentoProcesso. asp? incidente $=513$ 
VALLE, Vivian Cristina Lima López. CABRAL, Rodrigo Maciel. A responsabilização dos agentes públicos com o advento da lei no 13.655/2018: da teoria da irresponsabilidade estatal ao erro grosseiro. Revista Eletrônica Direito e Política, Programa de Pós-Graduação Stricto Sensu em Ciência Jurídica da UNIVALI, Itajaí, v.15, n.3, 30 quadrimestre de 2020. Disponível em: www.univali.br/direitoepolitica - ISSN 1980-7791

A despeito da decisão tomada pelo STF, ressalte-se que o art. $37, \S 6^{\circ}$ da Constituição estabelece a responsabilidade objetiva do Estado como regra, afastando disposições contrárias pela superioridade hierárquica da norma. ${ }^{63}$ Ainda, a obrigatoriedade da utilização do instrumento processual da denunciação à lide do agente público em ação de apuração de responsabilidade do Estado também afeta a regra prevista na Constituição, tendo em vista que transforma o paradigma da responsabilidade objetiva em subjetiva. ${ }^{64}$ Assim, separa-se a apuração da culpa ou dolo do agente para outro momento processual, sob pena de desvirtuação da responsabilidade objetiva do Estado. Este é o entendimento que se extrai de outros julgados do próprio Supremo Tribunal Federal. ${ }^{65}$

No entanto, cabe ressalva no tocante ao impacto do Decreto 9.830/2019 no tocante à regulamentação da culpa in vigilando. Esta modalidade de culpa é referente ao dever de fiscalização dos superiores hierárquicos aos demais agentes subordinados e, conforme texto do Decreto, depende de configuração de dolo ou erro grosseiro (art. $12, \S 5^{\circ}$ ). Portanto, no tocante à culpa in vigilando,

6782\&numeroProcesso $=1027633$ \& classeProcesso $=$ RE\&numeroTema $=940$. Acesso em 04 de setembro de 2019.

${ }^{63}$ Não adentra-se no aspecto dos casos em que o agente público assume responsabilidade em decorrência de instrumentos contratuais ou de prestação de constas, os quais possuem regime jurídico diferenciado da responsabilidade extracontratual.

64 OLIVEIRA, José Riberto Pimenta. O Direito de Regresso do Estado Decorrente do Reconhecimento de Responsabilidade Civil Extracontratual no Exercício da Função Administrativa. In: GUERRA, Alexandre Dartanhan de Mello; PIRES, Luis Manuel Fonseca; BENACCHIO, Marcelo (coord.) Responsabilidade Civil do Estado. São Paulo: Quartier Latin, 2010. P. 1130.

${ }^{65}$ Cite-se que este entendimento prevalece há tempos na jurisprudência do STF, conforme se vê no julgamento do Recurso Extraordinário no 327904 e até em entendimento mais recente por meio do ARE no 991.086: "EMENTA DIREITO ADMINISTRATIVO. RECURSO EXTRAORDINÁRIO INTERPOSTO SOB A ÉGIDE DO CPC/1973. RESPONSABILIDADE OBJETIVA DO ESTADO. REPARAČ̃̃O DE DANOS. AGENTE PÚBLICO. ILEGITIMIDADE PASSIVA AD CAUSAM. CONSONÂNCIA DA DECISÃO RECORRIDA COM A JURISPRUDÊNCIA CRISTALIZADA DO SUPREMO TRIBUNAL FEDERAL. RECURSO EXTRAORDINÁRIO QUE NÃO MERECE TRÂNSITO. REELABORAÇÃO DA MOLDURA FÁTICA. PROCEDIMENTO VEDADO NA INSTÂNCIA EXTRAORDINÁRIA. AGRAVO MANEJADO SOB A VIGÊNCIA DO CPC/2015. 1. O entendimento da Corte de origem, nos moldes do assinalado na decisão agravada, não diverge da jurisprudência firmada no Supremo Tribunal Federal. Esta Suprema Corte firmou o entendimento de que "somente as pessoas jurídicas de direito público, ou as pessoas jurídicas de direito privado que prestem serviços públicos, é que poderão responder, objetivamente, pela reparação de danos a terceiros. Isto por ato ou omissão dos respectivos agentes, agindo estes na qualidade de agentes públicos, e não como pessoas comuns". Precedentes: RE 228.977, Rel. Min. Neri da Silveira, $2^{\mathrm{a}}$ Turma; 327.904, Rel. Min. Ayres Britto, $1^{\text {a }}$ Turma; RE 470.996-AGR, Rel. Min. Eros Grau, 2a Turma; RE 344.133, Rel. Min. Marco Aurélio, $1^{\text {a }}$ Turma; RE 593.525-AgR-segundo, Rel. Min. Roberto Barroso, $1^{\text {a }}$ Turma; ARE 939.966AgR, Rel. Min. Dias Toffoli, $2^{a}$ Turma. 2. As razões do agravo regimental não se mostram aptas a infirmar os fundamentos que lastrearam a decisão agravada. 3. Agravo regimental conhecido e não provido." (In: STF. ARE 991086 AgR, Relator(a): Min. ROSA WEBER, Primeira Turma, julgado em 06/03/2018, DJe-055 DIVULG 20-03-2018 Publicação 21-03-2018). 
VALLE, Vivian Cristina Lima López. CABRAL, Rodrigo Maciel. A responsabilização dos agentes públicos com o advento da lei no 13.655/2018: da teoria da irresponsabilidade estatal ao erro grosseiro. Revista Eletrônica Direito e Política, Programa de Pós-Graduação Stricto Sensu em Ciência Jurídica da UNIVALI, Itajaí, v.15, n.3, 30 quadrimestre de 2020. Disponível em: www.univali.br/direitoepolitica - ISSN 1980-7791

de fato o Decreto regulamentou os casos de aplicação de responsabilidade aos superiores hierárquicos, excluindo a modalidade culposa.

\section{CONSIDERAÇÕES FINAIS}

A evolução histórica da responsabilidade civil extracontratual do Estado e a possibilidade de responsabilização pessoal dos agentes públicos passaram por grandes transformações ao longo do tempo e sempre levantam novas discussões. A gênese do erro grosseiro com a Lei no $13.655 / 2018$ e regulamentação pelo Decreto no 9.830/2019 torna imprescindíveis novas análises de tais institutos.

O objetivo da criação da referida Lei é o desenvolvimento de parâmetros para tomada de decisão, a fim de proporcionar segurança jurídica. No entanto, tal objetivo torna-se intangível, diante da criação de tantos conceitos indeterminados, que geram efeito reverso. É certo dizer que a conceituação de erro grosseiro pelo Decreto no 9.830/2019 ainda releva alto grau de abstração, ao determinar que o erro grosseiro é aquele "manifesto, evidente e inescusável" e praticado com "elevado grau" de culpa. Compreende-se, assim, o porquê de tantas discussões sobre o tema.

Há de se ressaltar que a segurança jurídica possui proteção expressa na Lei de Processo Administrativo Federal (Lei no 9.784/99) e, enquanto princípio, sob uma perspectiva pós-positivista, detém caráter normativo e cogente. ${ }^{66}$

Com base na ausência de conceituação de erro grosseiro na nova LINDB, a doutrina e a jurisprudência firmaram seus entendimentos de similaridade desde conceito com aquele utilizado para configurar culpa grave. ${ }^{67}$ No entanto, a regulamentação por meio do Decreto no 9.830/2019 afasta os dois conceitos e, com base neste distanciamento, não se pode admitir que a regulamentação nova

66 NOHARA, Irene Patrícia. Ensaio sobre a ambivalência da segurança jurídica nas relações do Estado: da realização de justiça à faceta perversa do argumento. In: MARRARA, Thiago (org.) Princípios de Direito Administrativo: Legalidade, Segurança Jurídica, Impessoalidade, Publicidade, Motivação, Eficiência, Moralidade, Razoabilidade, Interesse Público. São Paulo: Atlas, 2012. P. 73.

67 No TCU, o entendimento era exaurido pelo Acórdão no 1.628/2018 - Plenário; Na doutrina, temos o posicionamento de Thiago Valiatti, Manoela Munhoz e dos enunciados do IBDA, supramencionados. 
VALLE, Vivian Cristina Lima López. CABRAL, Rodrigo Maciel. A responsabilização dos agentes públicos com o advento da lei no 13.655/2018: da teoria da irresponsabilidade estatal ao erro grosseiro. Revista Eletrônica Direito e Política, Programa de Pós-Graduação Stricto Sensu em Ciência Jurídica da UNIVALI, Itajaí, v.15, n.3, 30 quadrimestre de 2020. Disponível em: www.univali.br/direitoepolitica - ISSN 1980-7791

e geral afaste as disposições de leis anteriores, hierarquicamente superiores (no caso da Constituição) ou específicas (no tocante à Lei de Improbidade Administrativa).

Ressalte-se, inclusive, que se tal dispositivo pretender obter a responsabilidade pessoal do agente mediante acionamento direto pelo particular, implicará em ofensa ao dispositivo constitucional.

Portanto, não há regulamentação no que tange ao direito de regresso previsto na Constituição; outrossim não há alteração de interpretação ou revogação da Lei de Improbidade no tocante ao elemento subjetivo da conduta do art. 10. Ao cabo, significa dizer que o agente público pode ser responsabilizado por suas decisões e opiniões técnicas eivadas de erro grosseiro como uma nova espécie de imputação de responsabilidade por danos ao erário, sem que isso configure improbidade administrativa ou implique em nova regulamentação do art. 37, $\S 6^{\circ}$.

Contudo, não se pode olvidar que o devido processo legal possui importante papel para limitação do exercício abusivo do poder, assim como o princípio da razoabilidade exprime ideais essenciais de justiça e proibição de excessos na Administração Pública. ${ }^{68}$ Assim, importante destacar que toda e qualquer responsabilização de agentes públicos deve obedecer aos parâmetros norteados pelos princípios basilares do Direito Administrativo, demonstrando-se principalmente a existência de congruência lógica entre os motivos de fato e a aplicação da sanção, ${ }^{69}$ sobretudo na caracterização da responsabilidade por erro grosseiro.

68 ZARDO, Francisco. Reflexão sobre a responsabilidade objetiva da Lei Anticorrupção (Lei 12.846/2013). In: DOTTI, René Ariel; DOTTI, Rogéria; ZARDO, Francisco (coord.) Temas de Direito Sancionador. São Paulo: Revista dos Tribunais, 2017. P. 23

${ }^{69}$ Nos termos do Decreto no 9.830/2019: "Art. $2^{\circ}$ A decisão será motivada com a contextualização dos fatos, quando cabível, e com a indicação dos fundamentos de mérito e jurídicos. $\S 1^{\circ} \mathrm{A}$ motivação da decisão conterá os seus fundamentos e apresentará a congruência entre as normas e os fatos que a embasaram, de forma argumentativa. § $2^{\circ}$ A motivação indicará as normas, a interpretação jurídica, a jurisprudência ou a doutrina que a embasaram. § $30 \mathrm{~A}$ motivação poderá ser constituída por declaração de concordância com o conteúdo de notas técnicas, pareceres, informações, decisões ou propostas que precederam a decisão." 
VALLE, Vivian Cristina Lima López. CABRAL, Rodrigo Maciel. A responsabilização dos agentes públicos com o advento da lei no 13.655/2018: da teoria da irresponsabilidade estatal ao erro grosseiro. Revista Eletrônica Direito e Política, Programa de Pós-Graduação Stricto Sensu em Ciência Jurídica da UNIVALI, Itajaí, v.15, n.3, 30 quadrimestre de 2020. Disponível em: www.univali.br/direitoepolitica - ISSN 1980-7791

\section{REFERÊNCIAS DAS FONTES CITADAS}

BACELLAR FILHO, Romeu Felipe. Direito administrativo. São Paulo: Saraiva, 2008.

BACELLAR FILHO, Romeu Felipe. Responsabilidade Civil Extracontratual das Pessoas Jurídicas de Direito Privado Prestadoras de Serviço Público. Revista de Direito Administrativo e Constitucional - A \& C. Curitiba: Juruá, 2002.

BOBBIO, Norberto. Teoria do Ordenamento Jurídico. Tradução de Maria Celeste Cordeiro Leite dos Santos. Brasília: Editora Universidade de Brasília, 1995.

CÂMARA DOS DEPUTADOS. Diário da Câmara dos Deputados: ano LXXII, No 189, sexta-feira, 27 de outubro de 2017. Disponível em: http://imagem.camara.gov.br/Imagem/d/pdf/DCD0020171027001890000.PDF\# page $=324$. Acesso em: 02 de julho de 2019 .

CARVAlHO FILHO, José dos Santos. Manual de Direito Administrativo. São Paulo: Atlas, 2014.

CORVALÁN, Juan Gustavo. Derecho Administrativo em transición: reconfiguración de la relación entre la Administración, las normas y el Poder Judicial. Ciudad Autónoma de Buenos Aires: Astrea, 2016.

DELPIAZZO, Carlos. La responsabilidad estatal ante la huida del Derecho administrativo. A \& C - Revista de Direito Administrativo e Constitucional. Belo Horizonte, ano 9, n. 35, p.13-34, jan./mar. 2009.

DI PIETRO. Maria Sylvia Zanella. Direito Administrativo. 25a Ed. São Paulo: Atlas, 2012.

DOTTA, Alexandre Godoy; CABRAL, Rodrigo Maciel. Mínimo Existencial na Hermenêutica da Jurisprudência Brasileira Referente às Políticas Públicas Relativas ao Direito à Educação. Revista de Estudos Constitucionais, Hermenêutica e Teoria do Direito. a. 10. v.2. p. 138-149 mai./ago. 2018.

FARIA, Luzardo. Fundamentos para a adoção de um modelo preventivo de responsabilização civil do Estado. Revista de Direito Administrativo \& Constitucional - A\&C, Belo Horizonte, ano 17, n. 69, p. 211-241, jul./set. 2017.

FERRAZ, Luciano. Alteração da LINDB revoga parcialmente Lei de Improbidade Administrativa. Disponível em: https://www.conjur.com.br/2018-mai-10/interesse-publico-alteracao-lindbrevoga-parcialmente-lei-improbidade. Acesso em: 05 de julho de 2019.

FREITAS, Daniel Castanha de. A responsabilidade civil do Estado por atos lícitos como resposta à aplicação do princípio constitucional da supremacia do interesse público. Fórum Administrativo -FA, Belo Horizonte, ano 13, n .144, fev. 2013. 
VALLE, Vivian Cristina Lima López. CABRAL, Rodrigo Maciel. A responsabilização dos agentes públicos com o advento da lei no 13.655/2018: da teoria da irresponsabilidade estatal ao erro grosseiro. Revista Eletrônica Direito e Política, Programa de Pós-Graduação Stricto Sensu em Ciência Jurídica da UNIVALI, Itajaí, v.15, n.3, 30 quadrimestre de 2020. Disponível em: www.univali.br/direitoepolitica - ISSN 1980-7791

Disponível em: http://www.bidforum.com.br/bid/PDI0006.aspx?pdiCntd=85290. Acesso em: 27 de junho de 2019.

GASPARINI, Diógenes. Direito Administrativo. São Paulo: Saraiva, 2008.

GUIMARÃES, Edgar. Contornos da Responsabilidade Patrimonial do Estado. In: HACHEM, Daniel Wunder; GABARDO, Emerson; SALGADO, Eneida Desiree (coord.). Direito Administrativo e Suas Transformações Atuais homenagem ao professor Romeu Felipe Bacellar Filho: Anais do Seminário da Faculdade de Direito da Universidade Federal do Paraná. Curitiba: Íthala, 2016

HACHEM, Daniel Wunder. Responsabilidade Civil do Estado por omissão: uma proposta de releitura da teoria da faute du service. Revista Eletrônica de Direito do Estado. N. 38, abril/junho de 2014.

IBDA. Seminário promovido pelo IBDA aprova enunciados sobre a LINDB. Disponível em: http://ibda.com.br/noticia/seminario-promovido-pelo-ibdaaprova-enunciados-sobre-a-lindb. Acesso em: 02 de julho de 2019.

MARQUES NETO, Floriano de Azevedo; FREITAS, Rafael Véras de. $\mathbf{0}$ artigo 28 da nova LINDB: um regime jurídico para o administrador honesto. Disponível em: https://www.conjur.com.br/2018-mai-25/opiniao-lindb-regime-juridicoadministrador-honesto. Acesso em: 02 de julho de 2019.

MEDAUAR, Odete. Direito Administrativo Moderno. São Paulo: Revista dos Tribunais, 2008. p. 365.

MELLO, Celso Antônio Bandeira de. Curso de Direito Administrativo. Malheiros Editores: São Paulo, 2012.

NOHARA, Irene Patrícia. Ensaio sobre a ambivalência da segurança jurídica nas relações do Estado: da realização de justiça à faceta perversa do argumento. In: MARRARA, Thiago (org.) Princípios de Direito Administrativo: Legalidade, Segurança Jurídica, Impessoalidade, Publicidade, Motivação, Eficiência, Moralidade, Razoabilidade, Interesse Público. São Paulo: Atlas, 2012.

OLIVEIRA, José Riberto Pimenta. O Direito de Regresso do Estado Decorrente do Reconhecimento de Responsabilidade Civil Extracontratual no Exercício da Função Administrativa. In: GUERRA, Alexandre Dartanhan de Mello; PIRES, Luis Manuel Fonseca; BENACCHIO, Marcelo (coord.) Responsabilidade Civil do Estado. São Paulo: Quartier Latin, 2010.

PAIVA, Leonardo Lindroth de; LEINDORF, Cecilia de Aguilar. O usuário do serviço Público como consumidor: visões do direito administrativo e do consumidor e sua atual aplicação. In: BETTES, Janaína Maria; DE PAIVA, Leonardo Lindroth; Lucimara Deretti (coord.). Temas de Desenvolvimento e Socioambientalismo. Curitiba: CRV,2016.

PALMA, Juliana Bonacorsi de. É erro grosseiro divergir do TCU? Divergência fundamentada não enseja responsabilidade do gestor. Disponível em: 
VALLE, Vivian Cristina Lima López. CABRAL, Rodrigo Maciel. A responsabilização dos agentes públicos com o advento da lei no 13.655/2018: da teoria da irresponsabilidade estatal ao erro grosseiro. Revista Eletrônica Direito e Política, Programa de Pós-Graduação Stricto Sensu em Ciência Jurídica da UNIVALI, Itajaí, v.15, n.3, 30 quadrimestre de 2020. Disponível em: www.univali.br/direitoepolitica - ISSN 1980-7791

https://www.jota.info/opiniao-e-analise/colunas/controle-publico/e-errogrosseiro-divergir-do-tcu-21112019. Acesso em: 10 de dezembro de 2019.

SANTOS, Rodrigo Valgas dos. Nexo Causal e Excludentes da Responsabilidade Extracontratual do Estado. In: FREITAS, Juarez (org.). Responsabilidade Civil do Estado. São Paulo: Malheiros, 2006.

SEVERO, Sérgio. Tratado de Responsabilidade Pública. São Paulo: Saraiva, 2009. n. p.

STF. STF reconhece a imprescritibilidade de ação de ressarcimento decorrente de ato doloso de improbidade. Disponível em: http://www.stf.jus.br/portal/cms/verNoticiaDetalhe.asp?idConteudo=386249 Acesso em: 10 de julho de 2019.

STF. Repercussão Geral no 940 - Responsabilidade civil subjetiva do agente público por danos causados a terceiros, no exercício de atividade pública. Disponível em: http://www.stf.jus.br/portal/jurisprudenciaRepercussao/verAndamentoProcesso. asp ? incidente $=5136782 \&$ numeroProcesso $=1027633 \&$ classeProcesso $=$ RE $\&$ numer oTema $=940$. Acesso em: 04 de setembro de 2019.

TCU. Relatório de Auditoria no 024.434/2014-0, Acórdão no 1.628/2018 Plenário. Relator Min. Benjamin Zymler. Data da sessão: 18/07/2018.

TCU. Tomada de Contas Especial no 007.416/2013-0, Acórdão 2.391/2018 Plenário. Relator Min. Benjamin Zymler. Data da sessão: 17/10/2018.

TCU. Representação no 023.072/2017-2, Acórdão 1.941/2019 - Plenário. Relator Min. Augusto Nardes. Data da sessão: 21/08/2019.

TJPR. Relação de enunciados com base em precedentes interpretativos do Superior Tribunal de Justiça e das $4^{a}$ e $5^{a}$ câmaras cíveis do Tribunal de Justiça do Estado do Paraná. Disponível em: https://www.tjpr.jus.br/documents/18319/15916367/Novos+Precedentes+4+e+ 5+Camaras+ Civeis.pdf/f954f537-4d5e-06dd-1d10-bc7219d94aac. Acesso em: 10 de Agosto de 2019.

VALIATI, Thiago Priess; MUNHOZ, Manoela Virmond. O impacto interpretativo da Lei no 13.655/2018 na aplicação da Lei de Improbidade Administrativa: a confiança no agente público de boa-fé para inovar na Administração Pública. Revista Brasileira de Direito Público - RBDP. Belo Horizonte, ano 16, n. 62, p. 161-186, jul./set. 2018.

VALLE, Vivian Lima López. Contratos administrativos e um novo regime jurídico de prerrogativas contratuais na Administração Pública contemporânea: da unilateralidade ao consenso e do consenso à unilateralidade na relação contratual administrativa. Belo Horizonte: Fórum, 2018. 
VALLE, Vivian Cristina Lima López. CABRAL, Rodrigo Maciel. A responsabilização dos agentes públicos com o advento da lei no 13.655/2018: da teoria da irresponsabilidade estatal ao erro grosseiro. Revista Eletrônica Direito e Política, Programa de Pós-Graduação Stricto Sensu em Ciência Jurídica da UNIVALI, Itajaí, v.15, n.3, 30 quadrimestre de 2020. Disponível em: www.univali.br/direitoepolitica - ISSN 1980-7791

VALLE, Vivian Cristina Lima López. Serviço Público, Desenvolvimento Econômico e a Nova Contratualização da Administração Pública: o Desafio na Satisfação dos Direitos Fundamentais. In: BACELLAR FILHO, Romeu Felipe; GABARDO, Emerson; HACHEM,. Daniel Wunder (coord). Globalização, Direitos Fudnamentais e Direito Administrativo: novas perspectivas para 0 desenvolvimento econômico e socioambiental. Belo Horizonte: Fórum, 2011.

ZARDO, Francisco. Reflexão sobre a responsabilidade objetiva da Lei Anticorrupção (Lei 12.846/2013). In: DOTTI, René Ariel; DOTTI, Rogéria; ZARDO, Francisco (coord.) Temas de Direito Sancionador. São Paulo: Revista dos Tribunais, 2017.

ZOCKUN, Maurício. Responsabilidade Constitucional, a Responsabilidade do Obrigatoriedade da Prévia Indenização

Patrimonial do Estado: Matriz Estado por Atos Legislativos, a Parlamentar. São Paulo: Malheiros, 2010. 